\title{
Apical Dendrites of the Neocortex: Correlation between Sodium- and Calcium-dependent Spiking and Pyramidal Cell Morphology
}

\author{
Han G. Kim and Barry W. Connors \\ Department of Neuroscience, Division of Biology and Medicine, Brown University, Providence, Rhode Island 02192
}

\begin{abstract}
Apical dendrites and somata of layer $\mathbf{V}$ pyramidal neurons were recorded with tight-seal patch electrodes in a slice preparation of rat somatosensory cortex. Recording sites were confirmed by measurements of the electrode location and by staining with biocytin. Dendritic recordings were made along the main trunk of the apical dendrite, usually within layer IV, at distances from 100 to $500 \mu \mathrm{m}$ from the soma. Most cells recorded through the dendrite had a distinct enlargement of the apical trunk around the presumed recording site.
\end{abstract}

The electrical properties of apical dendrites were readily distinguishable from those of somata. Dendrites generated two types of response when injected with depolarizing current. Group I responses were relatively small and broad $\mathrm{Na}^{+-}$ dependent action potentials whose amplitude and rate-ofrise were negatively correlated with recording distance from the soma. Group II responses were complex, clustered firing patterns of $\mathrm{Na}^{+}$-dependent spikes together with higherthreshold slow spikes or plateaus; in these dendrites spike parameters were not correlated with distance from the soma. These two response groups were correlated with dendritic morphology: group I had significantly fewer oblique branches on the apical dendrite (5.5 vs 12.0 ) and a thinner apical trunk (2.0 vs $2.5 \mu \mathrm{m})$ than group II. TTX (1-2 $\mu \mathrm{m})$ selectively blocked fast dendritic spikes, but not slow spikes and plateaus. Blocking $\mathrm{Ca}^{2+}$ currents reduced complex firing patterns and suppressed high-threshold slow spikes. Physiological and pharmacological studies imply that slow spikes and plateau potentials were primarily generated by highthreshold $\mathrm{Ca}^{2+}$ channels in the apical dendrite. Stimulating axons of layer I elicited EPSPs on distal apical dendrites of layer $\mathbf{V}$ cells. Recordings from both groups of apical dendrites revealed that EPSPs triggered a variety of distally generated, all-or-nothing depolarizations.

The results show that voltage-dependent $\mathrm{Na}^{+}$and $\mathrm{Ca}^{2+}$ currents are present in distal apical dendrites, in variable densities. These currents significantly modify distal synaptic events. The prevalence and character of active dendritic spiking (and presumably of $\mathrm{Na}^{+}$and $\mathrm{Ca}^{2+}$ channel densities) correlate with the morphology of the apical dendritic tree.

[Key words: dendrite, pyramidal cell, neocortex, action potentials, sodium currents, calcium currents]

\footnotetext{
Received Jan. 15, 1993; revised June 9, 1993; accepted June 17, 1993.

We thank Cheryl Pulaski for excellent histological assistance. This work was supported by an NIMH postdoctoral traineeship (5T32-MH19118) to H.G.K., and by grants from the NIH (NS25983) and ONR (N00014-90-J-1701) to B.W.C.

Correspondence should be addressed to Dr. Barry W. Connors, Department of Neuroscience, Box G-M, Division of Biology and Medicine, Brown University, Providence, RI 02192.

Copyright (C) 1993 Society for Neuroscience $0270-6474 / 93 / 135301-11 \$ 05.00 / 0$
}

Pyramidal cells of the neocortex may have apical dendrites over $1 \mathrm{~mm}$ long, from the soma in layer $\mathrm{V}$ to outermost layer $\mathrm{I}$ (Feldman, 1984). Apical dendrites allow a single cell to combine synaptic inputs from several cortical layers. The transformation applied by the apical dendrite to its inputs depends critically upon the dendrite's biophysics, which are determined by its morphology and membrane properties (Rall, 1977). Although the shapes of dendrites can often be measured with precision (Hillman, 1979), the electrical properties of their membranes have long been elusive.

At least some apical dendrites in neocortex are probably electrically excitable. Small spike-like potentials recorded in somata of immature pyramidal tract cells were attributed to dendritic electrogenesis (Purpura and Shofer, 1964; Purpura et al., 1965; Purpura, 1967), as were much slower somatic depolarizations from mature cells (Arikuni and Ochs, 1973). Somatic recordings of thalamocortical synaptic potentials also included small allor-none depolarizing events that were not blocked in an antidromic collision test, suggesting a dendritic origin (Deschênes, 1981). Direct measurements provide the clearest evidence for active apical dendrites. Patch-clamp recordings from dissociated cells reveal $\mathrm{Na}^{+}$channels in the proximal apical dendrite of immature pyramidal neurons (Huguenard et al., 1989). Intradendritic recordings with conventional sharp microelectrodes in vivo (Pockberger, 1991) showed complex active responses, and studies in vitro suggest that these may be mediated by both $\mathrm{Na}^{+}$- and $\mathrm{Ca}^{2+}$-dependent currents (Amitai et al., 1993).

Active membrane currents have been demonstrated in the dendrites of many neurons; however, they are very variable and cell type specific (Spencer and Kandel, 1961; Llinás and Nicholson, 1971; Wong et al., 1979; Llinás and Sugimori, 1981; Turner et al., 1991). For example, Purkinje cell dendrites seem to be dominated by active $\mathrm{Ca}^{2+}$ currents (Llinás and Sugimori, 1981; Ross et al., 1990; but see Regehr et al., 1992), while hippocampal dendrites can apparently sustain $\mathrm{Na}^{+}-$as well as $\mathrm{Ca}^{2+}$-dependent regenerative events (Wong et al., 1979; Benardo et al., 1982). Pyramidal neurons of neocortical layer $V$ are diverse in both structure and electrophysiology (Connors et al., 1982; Stafstrom et al., 1984; McCormick et al., 1985; ChagnacAmitai et al., 1990; Connors and Gutnick, 1990; Mason and Larkman, 1990; Silva et al., 1991; Agmon and Connors, 1992). It is possible that different types of pyramidal cells exhibit distinct forms of dendritic electrogenesis, and the variability of intradendritic recordings is consistent with this (Woody et al., 1984; Pockberger, 1991; Amitai et al., 1993). It is therefore important to characterize the active conductances in the apical dendrites, and their variations among different classes of neurons.

Conventional intracellular microelectrodes are not well suited 


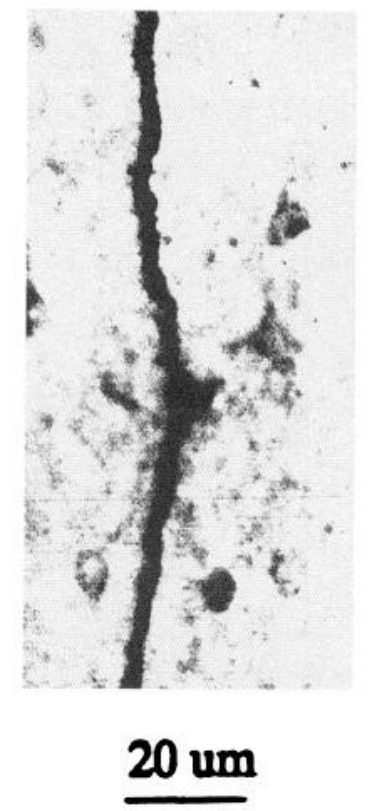

Figure 1. Dendritic recording site of a biocytin-filled apical dendrite. Slight swelling along the apical trunk corresponded closely to the calculated recording site. Scale bar, $20 \mu \mathrm{m}$.

to the study of small cellular structures such as dendrites. Tightseal methods, however, have made small cells much more accessible (Sakmann and Neher, 1983). Using the whole-cell variation of this technique, we have routinely obtained recordings from apical dendrites of layer V cells (Kim and Connors, 1992). Our results show that the dendrites have active $\mathrm{Na}^{+}$currents and high-threshold $\mathrm{Ca}^{2+}$ currents, and that dendritic morphology and dendritic electrogenesis are correlated.

\section{Materials and Methods}

Slice preparation. Animals were anesthetized by intraperitoneal injection of nembutal $(60 \mathrm{mg} / \mathrm{kg})$. After decapitation, the brain was quickly removed into cold $\left(6-8^{\circ} \mathrm{C}\right)$ physiological solution containing $(\mathrm{mm}) \mathrm{NaCl}$, 126; $\mathrm{KCl}, 3 ; \mathrm{NaH}_{2} \mathrm{PO}_{4}, 1.25 ; \mathrm{NaHCO}_{3}, 2.6 ; \mathrm{MgSO}_{4}, 1$; dextrose, 20; and $\mathrm{CaCl}_{2}, 2$; solutions were continuously bubbled with $95 \% \mathrm{O}_{2}, 5 \%$ $\mathrm{CO}_{2}$. A block of parietal neocortex was dissected and glued to the slicing platform of a vibratome. Coronal slices $400 \mu \mathrm{m}$ thick were cut from the primary somatosensory area. These slices were kept at room temperature in oxygenated physiological solution until use. The recording chamber was made from Teflon, surrounded by brass, and heated with an element to $35^{\circ} \mathrm{C}$. Slices were submerged and stabilized using a fine nylon net attached to a metal ring (Edwards et al., 1989). The chamber was perfused with oxygenated physiological solution; a peristaltic pump removed the effluent and controlled the fluid level. The chamber volume was less than $1 \mathrm{ml}$, the flow rate was $2-4 \mathrm{ml} / \mathrm{min}$, and the entire chamber solution was exchanged in about $3-4 \mathrm{~min}$. Drug solutions flowed through a small mixing chamber with several taps.

Whole-cell recording and staining methods. The methods for tightseal patch recordings followed Hamill et al. (1981), with modifications for brain slices (Blanton et al., 1989; Edwards et al., 1989). Patch electrodes were made from borosilicate tubing $(1.2 \mathrm{~mm}$ o.d., $0.9 \mathrm{~mm}$ i.d.) using a horizontal puller (Sutter Instruments). Electrode resistances were 4-8 M 2 . The standard intracellular solution contained (mM) $\mathrm{KCH}_{4} \mathrm{O}_{3} \mathrm{~S}$, 120; HEPES, 10; EGTA, 5; $\mathrm{MgCl}_{2}, 2$; $\mathrm{MgATP}, 4 ; \mathrm{CaCl}_{2}, 0.5 ; \mathrm{KCl}, 10$; and biocytin, $1 \%$, at $\mathrm{pH} 7.3$. During recording, some laminar boundaries were visualized under the dissecting microscope using transillumination (Agmon and Connors, 1991). To obtain whole-cell recordings, electrodes were advanced into the slice while pulsing with $0.1 \mathrm{nA}$ current steps of $200 \mathrm{msec}$ duration. When a significant increase in electrode resistance was evident, gentle suction was applied to obtain a seal resistance of $1 \mathrm{G} \Omega$ or greater. The patch of membrane was broken by applying more negative pressure to obtain a whole-cell configuration.

At the end of each recording, the position of the electrode between the pia and the white matter was measured using a calibrated eyepiece on the microscope. The slice was fixed with $4 \%$ paraformaldehyde and resectioned at $125 \mu \mathrm{m}$ on a freezing microtome. Sections were processed with the avidin-biotin-peroxidase method to reveal the cell morphology (Horikawa and Armstrong, 1988). Cells were photographed and drawn with the aid of a computerized reconstruction system (Neurolucida). Dendritically recorded cells usually had a discrete swelling and/or a slight kink along the trunk of their apical dendrite (Fig. 1; $n=22$ of 25 dendritic recordings); the position of this anomaly always corresponded well with the estimated position of the recording, as determined by measurement during the experiment. These dendritic structures were never observed in cells that were recorded from somata, nor have they been reported in Golgi studies (Feldman, 1984). Thus, we assume the swelling indicates the precise site of dendritic recording, and these were used to quantify distances between soma and recording site (e.g., see Fig. 4). Somatic membrane areas (SA) were estimated from the formula $\mathrm{SA}=\pi a b$, where $a$ is the major diameter and $b$ is the minor diameter of the soma (Larkman, 1991b).

Computational modeling of dendritic excitability. A computer model derived from a somatically recorded, biocytin-filled, layer $\mathrm{V}$ pyramidal cell was used to explore the relationship between dendritic spike shape and $\mathrm{Na}^{+}$channel density. The details of this cell, the model, and its implementation have been described in detail (Cauller and Connors, 1992; Amitai et al., 1993). In brief, the neuron was modeled by 120 linked, isopotential cylindrical compartments, with the apical dendrite fully represented, the basal dendrites lumped into a single equivalent cylinder, and an initial axon segment appended to the soma. Simulations were made with the program NEURON (Hines, 1989). Specific membrane capacitance $\left(C_{m}\right)$ was assumed to be $1 \mu \mathrm{F} / \mathrm{cm}^{2}$, specific membrane resistivity $\left(R_{m}\right)$ was $8014 \Omega \cdot \mathrm{cm}^{2}$, and specific cytoplasmic resistivity $\left(R_{i}\right)$ was $69 \Omega \cdot \mathrm{cm}^{2}$. Hodgkin and Huxley-type $\mathrm{Na}^{+}$and $\mathrm{K}^{+}$channels were added to the soma and initial segment compartments, with channel densities and kinetics adjusted to generate a somatic action potential about $100 \mathrm{mV}$ in amplitude, with a peak upward slope of $300 \mathrm{~V} / \mathrm{sec}$, and a duration of about $1 \mathrm{msec}$ at the base. The principle variable in the simulations reported here was the density of $\mathrm{Na}^{+}$and $\mathrm{K}^{+}$channels in the apical dendrite; these varied from zero (i.e., passive dendritic membrane) to $\overline{g_{\mathrm{Na}}}=0.096 \mathrm{~S} / \mathrm{cm}^{2}$, keeping a constant ratio of $\overline{g_{\mathrm{Na}}: \overline{g_{\mathrm{K}}}}=$ 6.67. Active currents were distributed uniformly throughout all apical dendrites in every case. As the density of active currents in the apical dendrite was increased, the densities in the somatic compartment were reduced to maintain the amplitude and upward slope of the somatic spike at constant levels (Amitai et al., 1993).

\section{Results}

\section{Two groups of dendritic recordings}

Electrode tips placed into layer IV frequently recorded from the apical dendrites of pyramidal neurons whose somata were in layer V. All dendrites could generate discrete, all-or-none events when stimulated with step pulses of current passed through the electrode. The patterns of electrogenesis varied greatly between dendrites, however. About half of the dendrites $(n=13)$ generated low-amplitude, relatively fast action potentials; strong stimulation yielded regular, adapting patterns of similarly sized spikes (Fig. $2 A)$. In contrast, the remaining dendrites $(n=12)$ generated action potentials with very variable amplitudes and durations and complex, often irregular patterns (Fig. 2B). Four of the latter dendrites could produce depolarizing plateau potentials. Plateau durations were variable, and sometimes lasted as long as the stimulus current (Fig. 2C). For purposes of comparison, we will call dendrites of the first type (i.e., those with small, fast spikes of regular size and temporal pattern) group I, and dendrites of the second type (i.e., those with variable spike sizes, including plateaus, with complex temporal patterns) group II.

Under normal recording conditions, apical dendrites of layer V cells were readily distinguishable from somata by their responses to injected currents. Somata invariably generated much faster and larger-amplitude spikes than did dendrites, with re- 
A

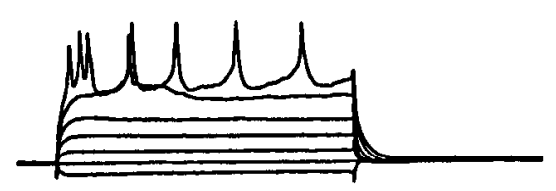

C

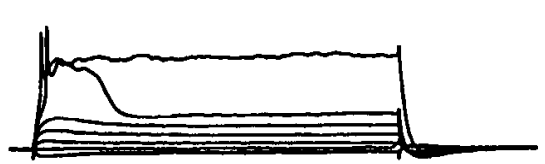

B

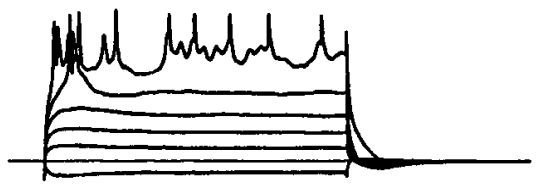

$\mathbf{D}$

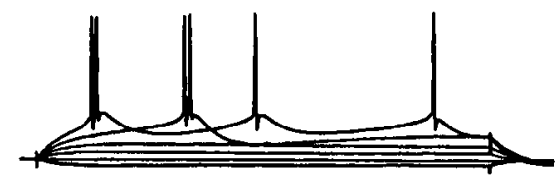

Figure 2. Examples of three different dendritic recordings and a somatic recording from layer $\mathrm{V}$ pyramidal cells. All cells were activated with rectangular current pulses incremented by $100 \mathrm{pA}$. $A$, Group I dendritic recording. Resting potential, $-63 \mathrm{mV}$; time calibration, $90 \mathrm{msec} . B$, Group II dendritic recording with complex fast-spike patterns and long depolarizing plateaus. Resting potential, $-70 \mathrm{mV}$; time calibration, 90 msec. $C$, Group II recording with a leading fast spike followed by variable duration plateaus. Resting potential, $-63 \mathrm{mV}$; time calibration, $50 \mathrm{msec} . D$, Somatic recording from a layer $\mathrm{V}$ pyramidal neuron. Resting potential, -71 ; time calibration, 40 msec. petitive firing patterns more similar to group I dendrites than group II (Fig. 2D). The passive electrical properties of somatic and dendritic recordings also differed. Dendritic recordings had more positive resting potentials, higher input resistances, and faster time constants (Table 1). Among the dendrites, the time constants for group I were significantly faster than those of group II (Table 2), but input resistance and resting potential did not differ.

\section{Correlations between dendritic physiology and morphology}

Apical dendrites of layer $\mathrm{V}$ pyramids vary greatly in diameter, length, and the number and pattern of distal tuft and proximal oblique branches (Larkman, 1991a). In our sample of dendritically filled cells it was not always possible to reconstruct the apical tufts reliably, since in some cases it seemed that portions had been cut off either during the initial slicing procedure or during histological processing. The rest of the cells were reasonably intact, however, and amenable to quantification.

When dendrites were grouped according to the physiological criteria defined above, distinct morphologies were evident. The most striking difference was the number of oblique branches from the apical trunks. Figure 3 shows examples of biocytinstained cells from group I (Fig. $3 A$ ) and group II (Fig. $3 B$ ). The approximate recording sites are marked by arrowheads, and each trunk with its oblique branches is shown isolated and enlarged. Group II dendrites had about twice as many primary oblique branches as group I, with little overlap between the two groups (Fig. 4, Table 2). Group I dendrites had thinner apical trunks, overall, than group II (Table 2). This may account for the fact that, on average, group II recording sites were significantly farther from the soma than those of group I, although there was considerable overlap in the distributions (Table 2). The distances between dendritic recordings sites and somata varied from about 100 to $470 \mu \mathrm{m}$.

The numbers of primary basal dendrites for group I (5.0 \pm $0.7)$ and group II $(5.3 \pm 1.5)$ neurons were the same. Estimated soma areas for the two groups were also similar (group $I=856$ $\pm 278 \mu \mathrm{m}^{2}$ and group II $=924 \pm 276 \mu \mathrm{m}^{2}$ ).

\section{Physiology of group I dendritic recordings}

Group I dendrites were similar to somata in their firing patterns, but dendritic spike amplitudes were smaller and longer lasting than those of layer V somata (Fig. 5, control traces; Table 3). Bath application of the $\mathrm{Na}^{+}$channel blocker TTX $(1 \mu \mathrm{M})$ eliminated most spiking activity in the group I dendrites $(n=6)$, leaving only a low-amplitude, regenerative series of spikes that was reversibly blocked by the substitution of $\mathrm{Mg}^{2+}$ for $\mathrm{Ca}^{2+}$ in the bathing medium (Fig. 5, left). The data imply that spikes in group I dendrites (as in somata) are primarily mediated by voltage-dependent $\mathrm{Na}^{+}$current, with a significant contribution from $\mathrm{Ca}^{2+}$ currents. By contrast, in somatic recordings $(n=4)$ it was not possible to evoke any regenerative events in the presence of TTX (Fig. 5, right). Somata did generate a graded, transient, TTX-insensitive depolarization that was blocked by $\mathrm{Ca}^{2+}$ removal.

\section{Physiology of group II dendritic recordings}

The most unique characteristic of group II dendrites was their ability to generate relatively large-amplitude, prolonged spikes or plateaus. Both $\mathrm{Na}^{+}$and $\mathrm{Ca}^{2+}$ conductances seem to contribute to this group II behavior. Figure $6 \mathrm{~A}$ shows a group II dendritic recording in which a suprathreshold current pulse elicited a fast spike followed by a broad spike. The expanded trace below shows both the fast and slow spikes clearly. Addition of $1 \mu \mathrm{M}$ TTX blocked the fast spikes, leaving a relatively large, slow, high-threshold spike that was reversibly blocked by $2 \mathrm{mM} \mathrm{Mg} \mathrm{Mg}^{2+}$ and $0 \mathrm{Ca}^{2+}$ (Fig. 6B). Notice that in the absence of the $\mathrm{Na}^{+}$ spike the voltage threshold of the slow spike increased (Fig. $6 B$, TTX).

Figure $7 A$ illustrates another group II dendritic recording under control conditions, showing both fast and slow spikes. Suppression of its $\mathrm{Ca}^{2+}$ currents with $2 \mathrm{~mm} \mathrm{Co}^{2+}$ (Fig. $7 B$ ) yielded

Table 1. Electrophysiology of dendritic and somatic recordings from layer $V$ pyramidal cells

\begin{tabular}{|c|c|c|}
\hline & Dendrites & Somata \\
\hline Resting potential $(\mathrm{mV})^{* *}$ & $-60.3 \pm 5.3, n=23$ & $-69.3 \pm 3.8, \quad n=18$ \\
\hline Input resistance $(\mathrm{M} \Omega)^{*}$ & $88.3 \pm 40, n=24$ & $68.8 \pm 27.3, n=16$ \\
\hline Time constant (msec) $)^{* *}$ & $7.3 \pm 2.9, n=25$ & $16 \pm 5.3, \quad n=21$ \\
\hline
\end{tabular}

Data are mean $\pm \mathrm{SD} ;{ }^{*}, p<0.1,{ }^{* *}, p<0.01$; two-tailed $t$ test assuming unequal variances. 
Table 2. Electrophysiology of group I and group II dendrites

\begin{tabular}{lcc} 
& Group I & Group II \\
\hline \# of oblique branches** & $5.5 \pm 3.4, n=13$ & $12 \pm 4.5, n=11$ \\
Apical trunk diameter $(\mu \mathrm{m})^{*}$ & $2.0 \pm 0.63, n=13$ & $2.5 \pm 0.45, n=10$ \\
Distance from recording site & & \\
$\quad$ to soma $(\mu \mathrm{m})^{* *}$ & $219 \pm 57, n=13$ & $336 \pm 100, n=11$ \\
Resting potential $(\mathrm{mV})$ & $-60.4 \pm 5.2, n=12$ & $-60.3 \pm 5.7, n=11$ \\
Input resistance (M $)$ & $95.1 \pm 39.6, n=13$ & $80.3 \pm 41, n=11$ \\
Time constant (msec)* & $8.6 \pm 2.6, n=12$ & $6 \pm 2.6, n=13$
\end{tabular}

Data are mean $\pm \mathrm{SD} ;{ }^{*}, p<0.05,{ }^{* *}, p<0.01$; two-tailed, $l$ lest assuming unequal variances.

spike patterns similar to those of group I dendrites. Taken together, the data suggest that group II cells have substantially larger $\mathrm{Ca}^{2+}$ currents in their apical dendrites than group I neurons.

\section{Spatial origins of $\mathrm{Ca}^{2+}$ and $\mathrm{Na}^{+}$spikes}

The channels that generate dendritic $\mathrm{Ca}^{2+}$ spikes in group II cells must be located on the apical dendritic membrane, rather than the soma or basal dendrites. This follows simply from the observation that dendrites, but not somata, displayed apparent $\mathrm{Ca}^{2+}$-dependent spikes under normal recording conditions, that is, without blocking $\mathrm{K}^{+}$currents (Fig. 6). The influence of $\mathrm{Ca}^{2+}$ currents may also be stronger in the apical dendrites of group I cells than in somata, as suggested by the data shown in Figure 5. Thus, it is likely that most layer $\mathrm{V}$ neurons have higher densities of $\mathrm{Ca}^{2+}$ current in their apical dendrites than in their somata.

The spatial origin of $\mathrm{Na}^{+}$-dependent dendritic events is more difficult to infer. Because group I dendritic spikes resemble truncated somatic spikes, they may be due primarily to the passive propagation of spikes generated by $\mathrm{Na}^{+}$channels within the perisomatic region (Turner et al., 1991; Amitai et al., 1993). Consistent with this, across all sampled group I dendrites the spike height diminished as the recording site moved farther from the soma (Fig. 8A). The correlation is significant $(r=-0.81)$. The maximal positive slope of the spike showed a similar relationship with recording distance (Fig. $8 B ; r=-0.70$ ). Ex- amples of proximal and distal group I recordings ( $a$ and $b$ in Fig. $8 A, B$ ) are illustrated in Figure $9, A$ and $B$.

Amplitudes and maximal slopes for the fast spikes of group II dendrites varied over wide ranges. For these measurements, only the first fast spike in an evoked train was measured, to avoid the confounding influences of subsequent $\mathrm{Ca}^{2+}$-dependent spikes and depolarization. Unlike group I, group II dendritic measurements did not correlate with the recording distance from the soma (Fig. $8 C, D$ ). Examples of group II responses ( $c$ and $d$ in Fig. $8 C, D$ ) are shown in Figure $9, C$ and $D$.

Results from computer simulations of $\mathrm{Na}^{+}$spikes in an apical dendritic trunk are illustrated in Figure 10, which plots the spike height and maximal slope as functions of distance from the soma, and dendritic $\mathrm{Na}^{+}$channel density. The model predicts that spike amplitude and slope will fall precipitously along the first $300 \mu \mathrm{m}$ of the apical trunk, if the dendritic membrane is passive (Fig. 10A,B, solid lines). This is similar to the relationship found for fast spikes in group I recordings (Figs. 8, 9). As dendritic $\mathrm{Na}^{+}$current density increases in the model, spike amplitude and slope become more complex functions of distance from the soma. Intermediate current densities display a dip in spike size within the first $200 \mu \mathrm{m}$, probably because of the impedance load of the apical oblique branches, followed by a distal increase in current density (Fig. 10, broken lines). Higher densities yield a dendrite that conducts like an axon (Fig. 10, dotted line). The results suggest that group I apical dendrites have a very low $\mathrm{Na}^{+}$channel density, at least in their trunks,
Figure 3. Morphology of group I $(A)$ and II $(B)$ cells. Group I cells had thinner apical dendrites and fewer oblique branches than group II cells. The enlarged figure on the right of each panel shows the same cell without the basal and distal apical dendrites. Arrowheads indicate the presumed recording sites. Physiology of the cell in $A$ is shown in Figure $9 A$, and the cell in $B$, in Figurc 7.
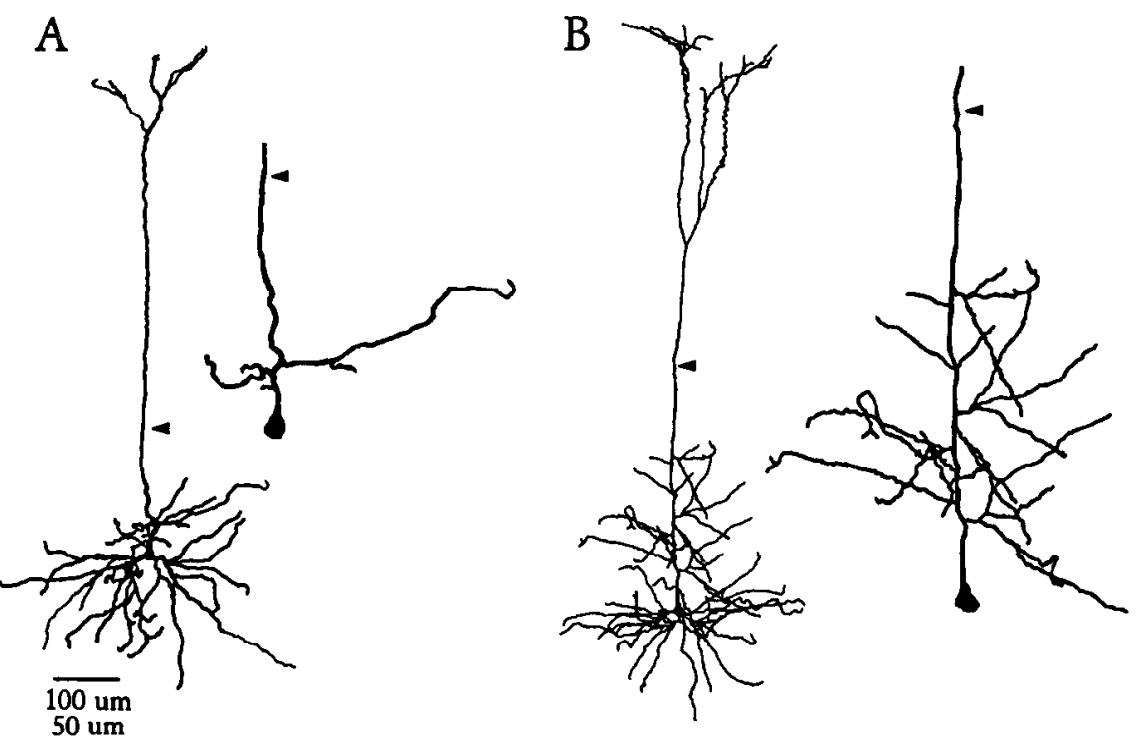


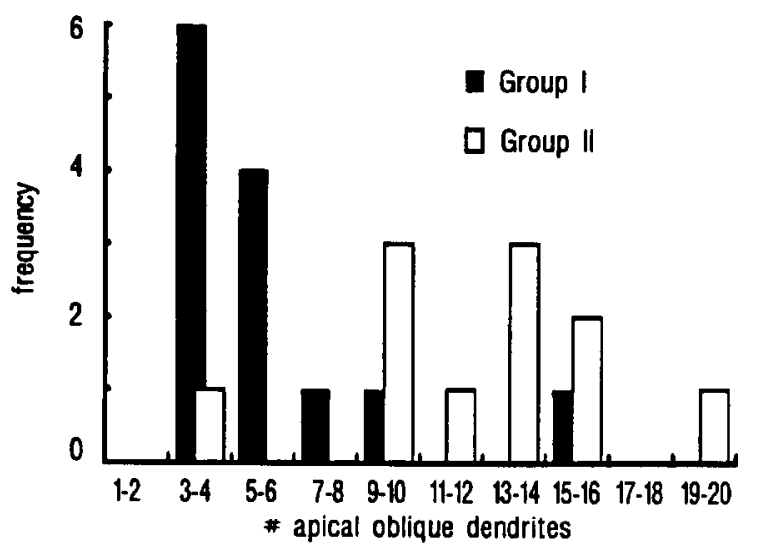

Figure 4. Plot of the number of the oblique branches from the apical trunk, for group I and II dendrites.

while group II dendrites are more variable, with at least some having $\mathrm{Na}^{+}$channel densities high enough to influence fastspiking ability strongly as far as $500 \mu \mathrm{m}$ from the soma (compare Figs. $8 C, D ; 9 C, D$ ).

\section{Characteristics of $\mathrm{Ca}^{2+}$ conductances}

Central neurons have a variety of active $\mathrm{Ca}^{2+}$ currents. Our data suggest that most of the $\mathrm{Ca}^{2+}$ current in the apical dendrite is of the high-threshold type. $\mathrm{Ca}^{2+}$-dependent spikes were activated only by large depolarizations, either on the trailing limbs of $\mathrm{Na}^{+}$spikes, or with injected currents following TTX blockade of $\mathrm{Na}^{+}$spikcs. The long durations of many dendritic $\mathrm{Ca}^{2+}$ spikes, even in the absence of $\mathrm{K}^{+}$channel blockers, also suggest that the underlying $\mathrm{Ca}^{2+}$ currents did not inactive rapidly (Figs. $2 C$, $7,9 C, D$ ). Voltage plateaus often did not repolarize until the end of a stimulus current pulse (up to $300 \mathrm{msec}$ duration).

Voltage clamping of apical dendrites was not feasible because of inadequate space clamp and the relatively high series resistance of the electrodes. However, pharmacological studies were also consistent with the presence of high-threshold $\mathrm{Ca}^{2+}$ cur-
Table 3. Comparison between fast action potentials of group I dendrites and layer $V$ somata

\begin{tabular}{lll} 
& Dendrites & Somata \\
\hline $\begin{array}{c}\text { Action potential } \\
\text { half-width }(\mathrm{msec})^{* *}\end{array}$ & $6.3 \pm 1.5, n=13$ & $2.6 \pm 0.86, n=21$ \\
$\begin{array}{c}\text { Action potential } \\
\text { height }(\mathrm{mV})^{* *}\end{array}$ & $23.7 \pm 8.7, n=13$ & $40.4 \pm 14.2, n=18$
\end{tabular}

Action potential height is measured from threshold voltage to peak depolarization; half-width is the duration at $50 \%$ of peak height. Data are mean $\pm \mathrm{SD} ;{ }^{* *}, p<$ 0.01 ; two-tailed, $t$ test assuming unequal variances.

rents. $\mathrm{Ni}^{2+}$ at a concentration of $100 \mu \mathrm{M}$ has a strong depressive action on low-threshold $\mathrm{Ca}^{2+}$ channels of rat dorsal root ganglia cells (Carbone et al., 1990). However, even $200 \mu \mathrm{M} \mathrm{Ni}{ }^{2+}$ did not have any noticeable effect on the $\mathrm{Ca}^{2+}$ spikes of group I dendrites, when $\mathrm{Na}^{+}$and $\mathrm{K}^{+}$currents were suppressed with TTX $(2 \mu \mathrm{M})$ and tetraethylammonium (TEA; $15 \mathrm{mM})$, respectively (Fig. $11 A, B ; n=3$ ). Only at $500 \mu \mathrm{M}$ did $\mathrm{Ni}^{2+}$ begin to have a noticeable suppressive effect (Fig. 11C), and even at 3 mM it did not block the dendritic $\mathrm{Ca}^{2+}$ spikes completely (not shown).

Unlike $\mathrm{Ni}^{2+}, \mathrm{Cd}^{2+}$ suppresses high-threshold $\mathrm{Ca}^{2+}$ channels at concentrations of $2-20 \mu \mathrm{M}$, while having no effect on lowthreshold channels (Fox et al., 1987). Figure $12 A$ shows a group II dendrite with complex firing patterns riding on a plateau potential. The plateau was reversibly suppressed by $10 \mu \mathrm{M} \mathrm{Cd}^{2+}$ (Fig. 12B;n=2), suggesting an involvement of high-threshold $\mathrm{Ca}^{2+}$ currents. Interestingly, $10 \mu \mathrm{M} \mathrm{Cd}^{2+}$ did not abolish all broad spikes in the illustrated case (Fig. 12B), although it did in another dendrite.

\section{Synaptic activation of dendritic spikes}

Activation of excitatory synapses in layer I can generate large, fast EPSPs in the somata of layer V pyramidal cells (Cauller and Connors, 1992). Stimulation of layer I while recording from the apical dendrites of layer $V$ cells generated EPSPs that always

\section{Group I Dendrite}

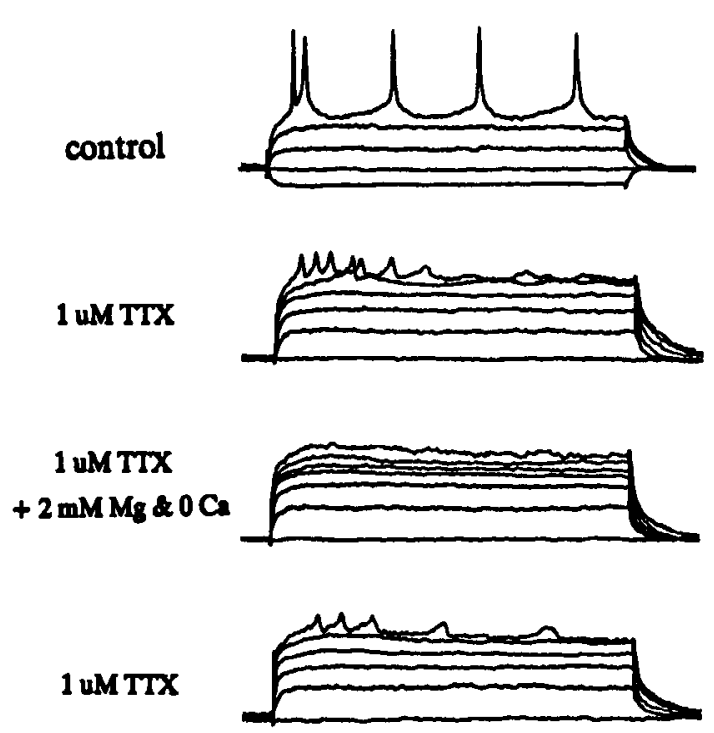

Layer V Soma
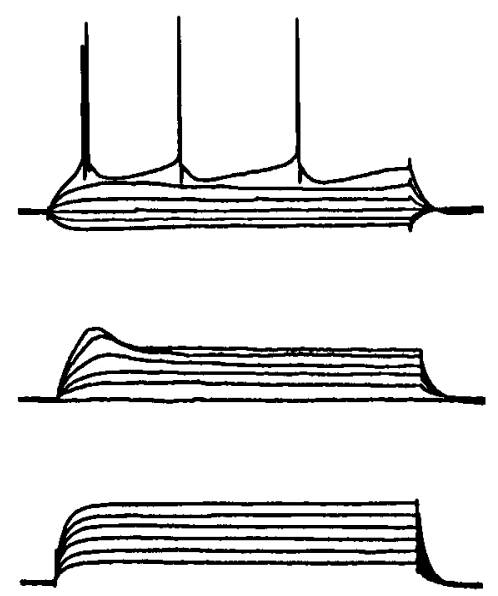

$20 \mathrm{mV}$

$90 \mathrm{msec}$
Figure 5. Effects of current blockade on recordings from a group I dendrite and a layer $V$ soma. Under control conditions, the dendrite resembled the soma in general firing pattern, but the dendritic spikes were broader and smaller. TTX $(1 \mu \mathrm{M})$ blocked fast spikes in both dendrite and soma. However, small, higher-threshold, repetitive spikes remained in the dendrite but not the soma. Blockade of $\mathrm{Ca}^{2+}$ currents by addition of extra $\mathrm{Mg}^{2+}(2 \mathrm{mM})$ and the removal of extracellular $\mathrm{Ca}^{2+}$ abolished the remaining small dendritic spikes, and suppressed the initial, graded depolarization in the soma. Resting potential of the dendrite was $-52 \mathrm{mV}$, current steps incremented by $100 \mathrm{pA}$; resting potential of the soma was $-68 \mathrm{mV}$, current steps incremented by $50 \mathrm{pA}$. 


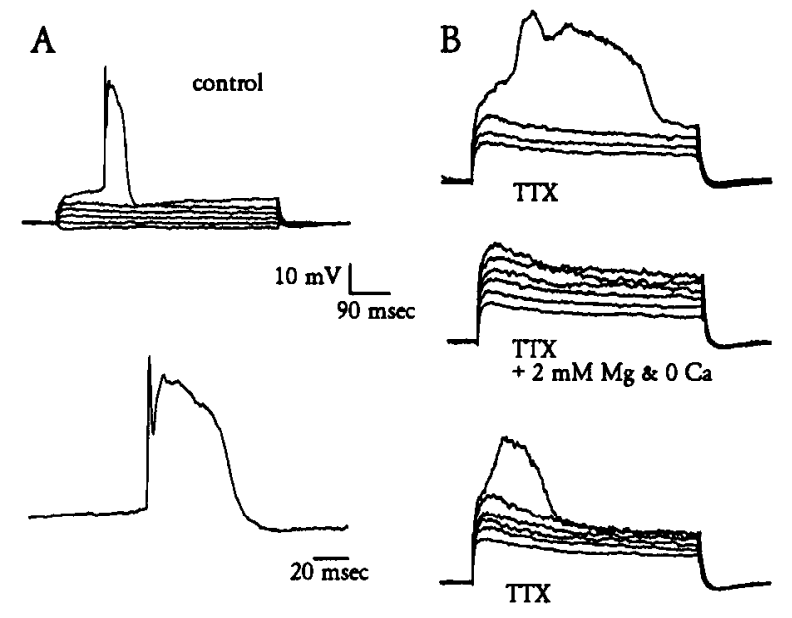

Figure 6. Effects of current blockade in a group II dendritic recording. $A$, Injected currents evoked an initial fast spike, followed by a longlasting spike under control conditions. The lower record shows an expanded trace of the spikes. $B$, Fast spikes were blocked by $1 \mu \mathrm{M}$ TTX, leaving a long-lasting spike with high threshold. The long-lasting spikes were reversibly blocked by additional $2 \mathrm{mM} \mathrm{Mg}^{2+}$ in the absence of $\mathrm{Ca}^{2+}$. Resting potential was $-56 \mathrm{mV}$. Current steps were incremented by $100 \mathrm{pA}$.

initiated all-or-none, fast and slow spikes. Figure $13 \mathrm{~A}$ shows recordings from a group II dendrite as stimulus intensity was increased; several discrete all-or-none events with different amplitudes and durations could be recruited, suggesting multiple locations for dendritic spike generation. Similar results were obtained in five of six group II dendrites tested. Figure $13 B$ illustrates a different group II dendrite, in which a layer I EPSP triggered two all-or-none events with different amplitudes and durations when recorded at the resting potential of $-56 \mathrm{mV}$. When the dendrite was hyperpolarized to $-73 \mathrm{mV}$ the slower, higher-threshold spike was blocked. Surprisingly, even group I dendrites reliably generated both fast and slow spikes when activated by distal EPSPs (six of six group I dendrites tested; Fig. 13C,D).

It is likely that many of the layer I-cvoked spikcs rccorded in dendritic trunks were actually initiated in the dendrites. In three of four group I dendrites, and two of three group II dendrites, the voltage threshold for fast-spike generation by a layer I EPSP was lower than the threshold when current was injected through the recording electrode. This implies that distal synapses may commonly trigger regenerative events within their local region of dendrite, in most types of layer $\mathrm{V}$ neuron.

\section{Discussion}

\section{Physiological and morphological diversity among apical dendrites}

This study confirms that the apical dendrites of many layer $\mathrm{V}$ pyramidal cells have complex, nonlinear membrane properties that often allow the generation of $\mathrm{Na}^{+}-$and $\mathrm{Ca}^{2+}$-dependent action potentials (Amitai et al., 1993). In addition, we found that the spiking characteristics of apical dendrites varied widcly, and that the complexity of spiking correlated with dendritic morphology. In general, apical dendrites with prominent $\mathrm{Ca}^{2+}$ dependent spikes and irregular patterns of $\mathrm{Na}^{+}$-dependent spikes (group II) had the most side branches and the largest trunk diameters. Dendrites with primarily fast, $\mathrm{Na}^{+}$-dependent spikes and more regular, soma-like temporal patterns (group I) tended to have fewer primary branches and narrower trunks.

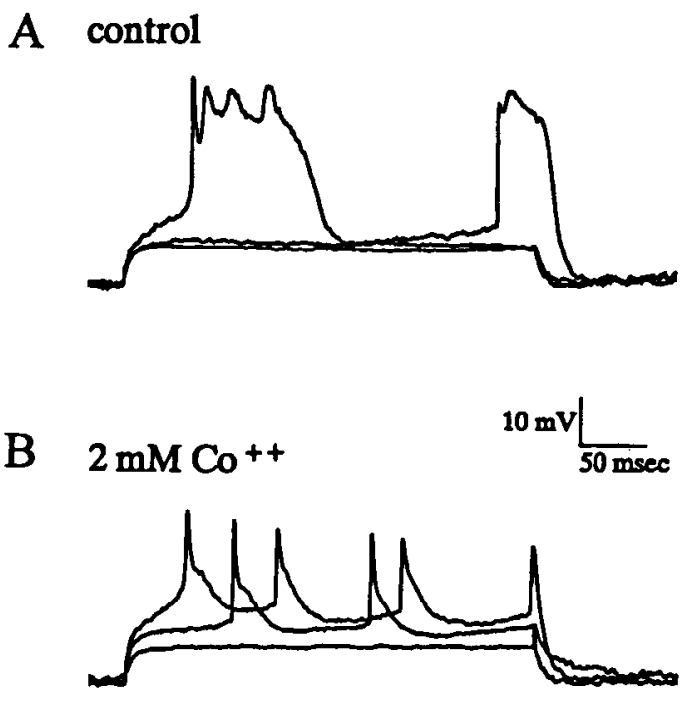

Figure 7. Blocking $\mathrm{Ca}^{2+}$ currents with $\mathrm{Co}^{2+}(2 \mathrm{~mm})$ converted group Il dendritic responses to group I-like responses.

Recordings from the somata of layer $\mathrm{V}$ pyramidal cells show a variety of intrinsic spiking patterns, including different rates of spike frequency adaptation and several forms of intrinsic bursting (Connors et al., 1982; Stafstrom et al., 1984; McCormick et al., 1985; Silva et al., 1991). Until somata and dendrites have been recorded simultaneously in single cells, we can only speculate about how the different types of each correspond. However, morphology can guide our conjecture. Somatic recordings from layer $\mathrm{V}$ cells have shown that intrinsically bursting neurons tend to be relatively large, with thicker and more arborizing apical dendrites than regular-spiking neurons (Chagnac-Amitai et al., 1990; Larkman and Mason, 1990). Judging from their morphology and complex spiking, it seems likely that at least some group II apical dendrites are attached to intrinsically bursting somata. Group I dendrites are most similar to regular-spiking somata in their firing patterns and morphology, and may correspond.

There is evidence that the apical dendrite does not significantly influence the firing patterns of the soma (Telfeian et al., 1991). The membrane properties of the apical dendrite may thus be disassociated from those of the soma, and the attributes of one may not fully predict the attributes of the other. A full characterization of a pyramidal cell will require separate idenlification of its somatic, basal, and apical dendritic physiology (P. A. Rhodes and C. M. Gray, unpublished observations).

\section{Origin of dendritic spikes}

$\mathrm{Ca}^{2+}$-dependent dendritic spikes are probably generated by $\mathrm{Ca}^{2+}$ channels in the dendrites, for the following reasons. First, it is not normally possible to observe slow $\mathrm{Ca}^{2+}$ spikes from the soma under normal recording conditions, but in dendritic recordings $\mathrm{Ca}^{2+}$ spikes are often prominent. Some intrinsically bursting cells generate a slow, $\mathrm{Ca}^{2+}$-dependent wave underlying the burst of fast spikes (Connors et al., 1982; McCormick et al., 1985), but its amplitude and duration are much smaller than is common in group II dendrites. Second, activation of layer I synapses often elicited slow, all-or-nothing events that could be selectively blocked by hyperpolarization, suggesting a distal site of slow spike generation. Third, if the sources of $\mathrm{Ca}^{2+}$ currents are in distal dendrites, it might be expected that the number 
A

Group I
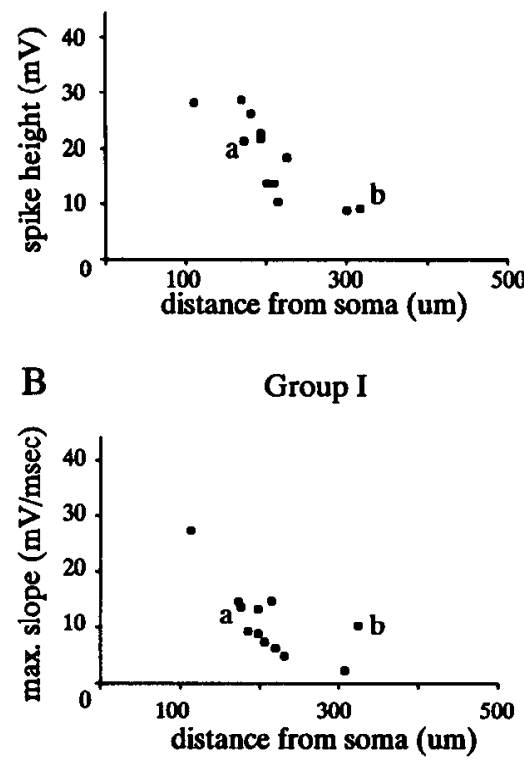

C

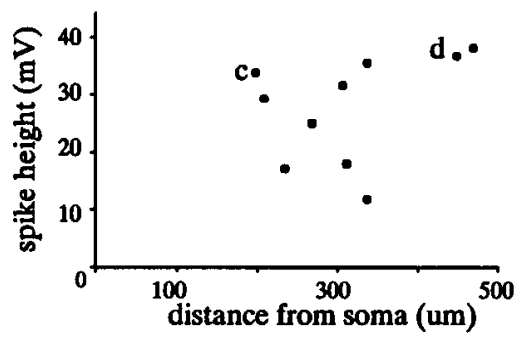

D

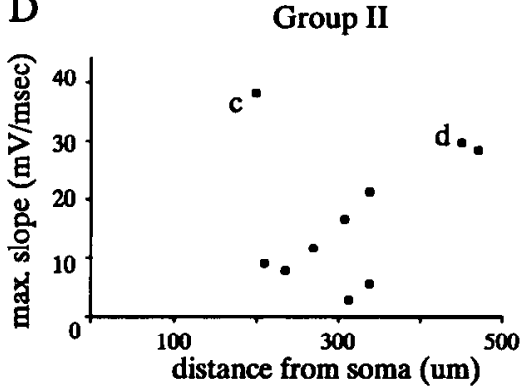

Figure 8. Plots of fast-spike height and maximal upstroke slope versus the distance between the soma and the recording site for group I and II dendrites. The group I spike height $(A)$ and maximal slope $(B)$ decreased as the recording distance increased. Both correlations are significant (for spike height, $r$ $=-0.81, p<0.01$; for maximal slope, $r=-0.7, p<0.01)$. Neither group II spike height $(C)$ nor maximal slope $(D)$ was correlated with distance from the soma. In each case, spike heights were measured from the threshold voltage. Only the first fast spike for each cell was used. Examples of proximal and distal group I and II recordings, labeled $a-d$, are shown in Figure $9 A-D$, respectively. and dimension of dendritic branches would correlate with the prevalence of $\mathrm{Ca}^{2+}$ spikes. Indeed group II recordings, which showed more prominent $\mathrm{Ca}^{2+}$ spikes than group I recordings, had larger apical dendrites and more oblique branches. Because of their proximity to the recording sites, the oblique branches would be the ones most likely to contribute significant current to the apical trunk.

Some apical dendrites may also support at least limited $\mathrm{Na}^{+}$ spiking, as suggested by Huguenard et al. (1989). Models of passive apical dendrites predict that spike size and rate-of-rise should fall precipitously with distance from a somatic generation site (Fig. 10). However, the size and rate-of-rise of $\mathrm{Na}^{+}$spikes from group II recordings did not correlate well with distance from the soma. Some dendritic sites $300-400 \mu \mathrm{m}$ from the soma generated relatively large fast spikes, implying that the $\mathrm{Na}^{+}$spike is not simply passively conducted from the soma. It is conceivable that the spike height may be somewhat influenced by subsequent $\mathrm{Ca}^{2+}$ spikes (Fig. 7). However, since $\mathrm{Ca}^{2+}$ spikes always followed the initial fast spike it seems unlikely that it might have boosted the fast-spike amplitude. It is even less likely to have influenced the slope of the spike upstroke, since the rising phase of the first spike substantially preceded the following $\mathrm{Ca}^{2+}$ spike (Fig. 6A). In addition, layer I EPSPs often triggered lowthreshold, fast spikes in apical dendrites. Thus, our data imply that group II dendrites can generate $\mathrm{Na}^{+}$as well as $\mathrm{Ca}^{2+}$ spikes.

It is less likely that group I dendrites have relatively high $\mathrm{Na}^{+}$ channel densities. Their spikes fell in size and speed as the recording site was moved away from the soma (Fig. 8). The repetitive firing patterns of group I recordings also resembled somatic $\mathrm{Na}^{+}$spike patterns (Fig. 5). Unlike spike amplitudes, the dendritic spike half-widths were not correlated with distance from the somata (not shown). However, spike duration is sensitive to many things besides passive electrotonic propagation. Dendritic $\mathrm{Ca}^{2+}$ currents, variations in $\mathrm{K}^{+}$currents or specific membrane resistivity, or small numbers of dendritic $\mathrm{Na}^{+}$channels themselves could affect duration. It is notable that layer I EPSPs triggered fast spikes in group I dendrites, but their site of origin is ambiguous.
Our data do not clearly address the distribution of $\mathrm{Na}^{+}$and $\mathrm{Ca}^{2+}$ channels within the apical dendrites. Because the prevalence of $\mathrm{Ca}^{2+}$-dependent potentials seems to correlate with the number of oblique dendritic branches, it may be that $\mathrm{Ca}^{2+}$ channels are enriched in more distal dendritic branches. Several recent studies bolster this possibility. Reuveni et al. (1993) have shown that $\mathrm{Ca}^{2+}$-dependent plateau potentials recorded in somata of pyramidal cells often decay stepwise rather than smoothly. Steps are reproduced in their computational model if high-threshold $\mathrm{Ca}^{2+}$ channels are distributed nonhomogeneously through the dendritic tree. Some of our dendrite recordings in the presence of TTX and TEA (Fig. 11) also showed stepwise decay of plateau potentials. Jaffe et al. (1992), using intracellular indicators of $\mathrm{Na}^{+}$and $\mathrm{Ca}^{2+}$ in hippocampal pyramidal cells, concluded that active $\mathrm{Na}^{+}$channels are located primarily on the soma and most proximal dendrites, while $\mathrm{Ca}^{2+}$ channels are spread along the entire dendritic tree. Finally, modeling results of Mel (in press) suggest that the apical trunk of a pyramidal cell is likely to be less active compared to more distal
$\mathbf{A}$

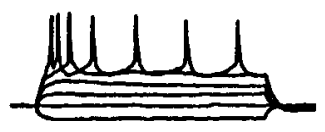

B

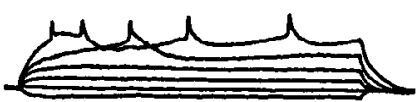

C

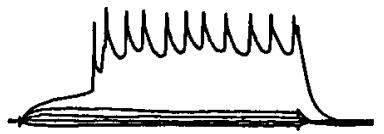

$20 \mathrm{mV} L$

D

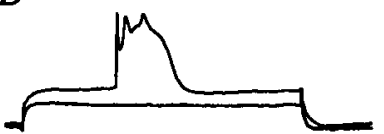

Figure 9. Examples of group I ( $A$ and $B)$ and II $(C$ and $D)$ recordings, marked in Figure 8 as $a-d$. $A$, Resting potential, $-52 \mathrm{mV} ; 100 \mathrm{pA}$ current; time calibration, 90 msec. $B$, Resting potential, $-58 \mathrm{mV} ; 100$ pA steps; time calibration, $40 \mathrm{msec}$. $C$, Resting potential, $-64 \mathrm{mV} ; 100$ pA steps; time calibration, $50 \mathrm{msec} . D$, Resting potential, $-65 \mathrm{mV} ; 300$ and $400 \mathrm{p} \Lambda$ steps, time calibration, $50 \mathrm{msec}$. 

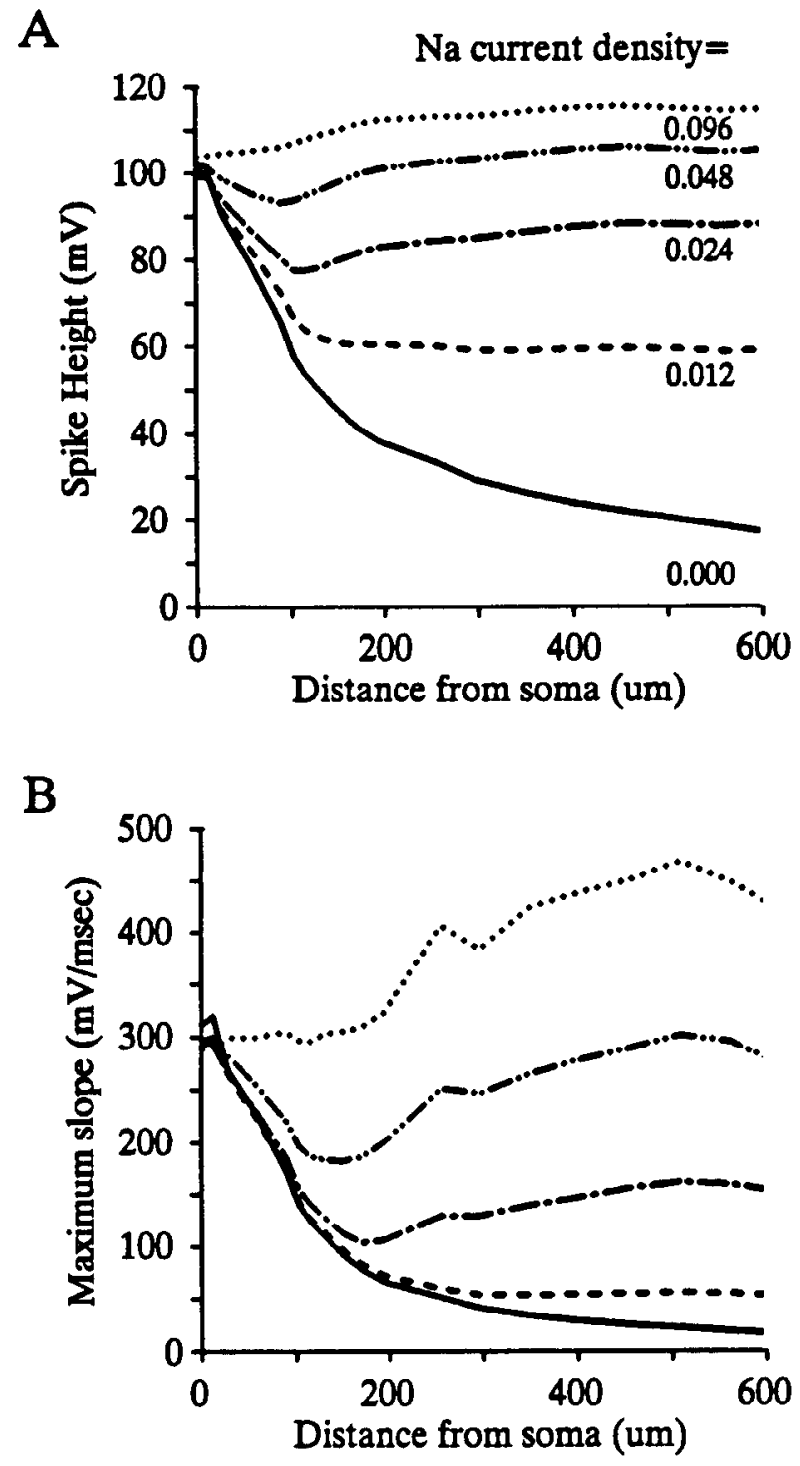

Figure 10. Modeling results showing computed relationship between fast-spike height $(A)$ and maximal slope $(B)$ as a function of distance along the apical trunk and $\mathrm{Na}^{+}$channel density. The neuron modeled was a large layer $\mathrm{V}$ pyramidal cell similar to those studied here (see Cauller and Connors, 1992).

branches; if slow, active conductances are too prominent in the proximal trunk, the soma behaves unrealistically. Only more refined measurements will illuminate the channel distribution on apical dendrites.

\section{Properties of dendritic $\mathrm{Ca}^{2}$ । currents}

The characterization of $\mathrm{Ca}^{2+}$ currents in neocortical neurons is very incomplete. In general, two classes of neuronal $\mathrm{Ca}^{2+}$ channels can be distinguished by kinetic criteria: a slowly inactivating, high voltage-threshold variety, and a rapidly inactivating, low voltage-threshold type (Tsien et al., 1988; Carbone and Swandulla, 1989; Llinás et al., 1989). Somatic recordings provide evidence for both low-threshold (Friedman and Gutnick, 1987; Sutor and Zieglgänsberger, 1987; Sayer et al., 1990; Giffin et al., 1991) and high-threshold (Stafstrom et al., 1985; Franz et al., 1986; Sayer et al., 1990; Giffin et al., 1991; Hamill et al., 1991) $\mathrm{Ca}^{2+}$ currents in pyramidal cells of neocortex. There may
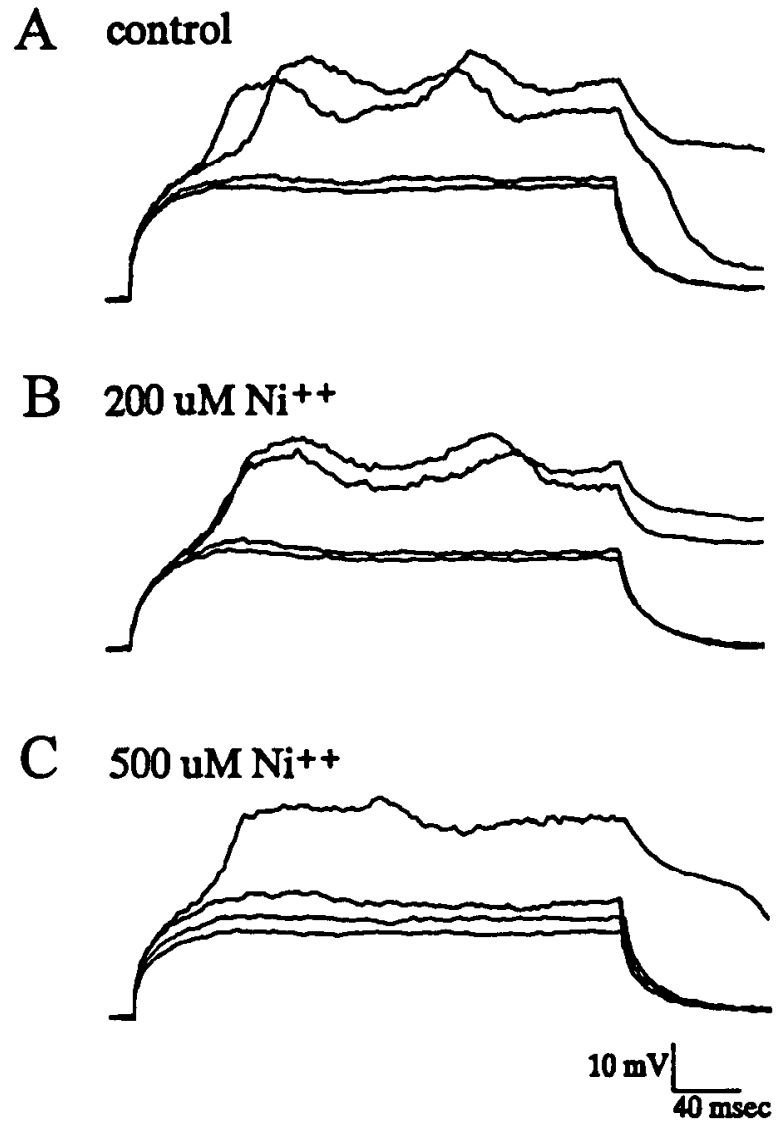

Figure 11. Effects of $\mathrm{Ni}^{2+}$ on dendritic $\mathrm{Ca}^{2+}$ spikes. A, Dendrite was bathed in $15 \mathrm{mM}$ TEA and $2 \mu \mathrm{M}$ TTX to isolate $\mathrm{Ca}^{2+}$-dependent events. $B$, At $200 \mu \mathrm{M}, \mathrm{Ni}^{2+}$ had no effect. C', At $500 \mu \mathrm{M}, \mathrm{Ni}^{2+}$ increased the threshold of $\mathrm{Ca}^{2+}$ spikes. At $3 \mathrm{mM} \mathrm{Ni}^{2+}$ spikes were blocked (not shown). Resting potential was $-43 \mathrm{mV}$; current increments were $100 \mathrm{pA}$, beginning at $500 \mathrm{pA}$.

be several varieties of high-threshold $\mathrm{Ca}^{2+}$ currents (i.e., $\mathrm{N}, \mathrm{L}$, and $\mathrm{P}$ ) present in a single cortical neuron (Brown et al., 1992), but the relative densities have not been determined.

The $\mathrm{Ca}^{2+}$ currents present in apical dendrites seem to be generated primarily by high-threshold channels. Dendritic $\mathrm{Ca}^{2+}$ spikes were always activated at high voltage levels, and they often did not inactivate over several hundred milliseconds (Figs. $2,6)$. Pharmacological studies also agree with this interpretation. In most neurons, a relatively low dose $(20 \mu \mathrm{M})$ of $\mathrm{Cd}^{2+}$ blocks high-threshold $\mathrm{Ca}^{2+}$ currents (i.e., L- and N-type) while not affecting low-threshold currents (i.e., T-type) (Fox et al., 1987). The partial effect of $\mathrm{Cd}^{2+}$ that we observed here (Fig. 12) may reflect the presence of some relatively $\mathrm{Cd}^{2+}$-insensitive $\mathrm{Ca}^{2+}$ currents, or it may simply be that the concentration of $\mathrm{Cd}^{2+}$ within the slice did not completely equilibrate with the bath level. $\mathrm{Ni}^{2+}(<100 \mu \mathrm{M})$ preferentially blocks low-threshold $\mathrm{Ca}^{2+}$ currents (Carbone et al., 1990). In the dendrites, $\mathrm{Ni}^{2+}$ at relatively high concentrations $(200 \mu \mathrm{M})$ did not block the $\mathrm{Ca}^{2+}$ currents, while $\mathrm{Cd}^{2+}$ at relatively low concentrations reduced the potential plateau. Consistent with the physiological data, immunocytochemical evidence implies that there are N-type calcium channels along apical dendrites of the neocortex (Westenbroek et al., 1992). Rigorous characterization of dendritic $\mathrm{Ca}^{2+}$ currents will require voltage-clamp measurements and pharmacological studies. 
A

control
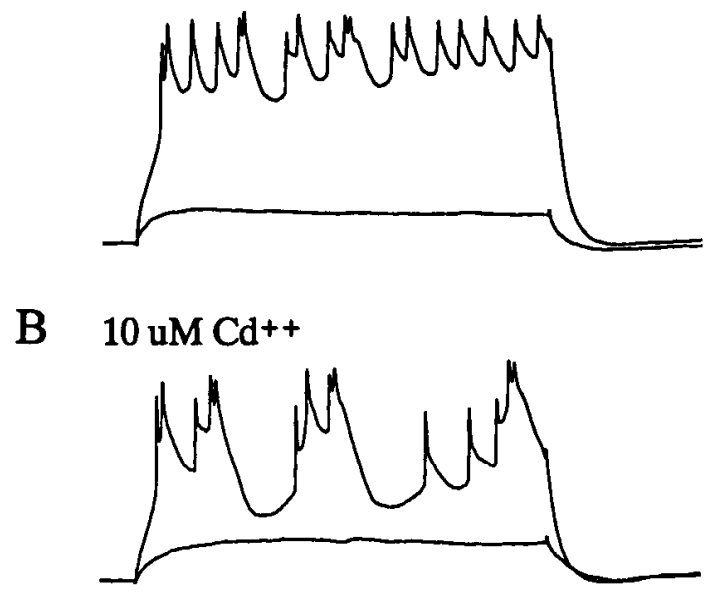

C recovery

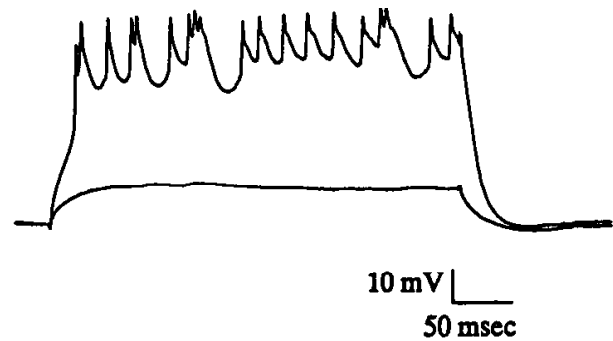

Figure 12. Effects of $\mathrm{Cd}^{2+}$ on dendritic $\mathrm{Ca}^{2+}$ spikes. A relatively low concentration of $\mathrm{Cd}^{2+}(10 \mu \mathrm{M})$ reduced the plateau potential, but did not completely block slow spikes. Resting potential was $-62 \mathrm{mV}$.

\section{Functional implications of excitable dendrites}

The precise functions of active dendritic conductances are unknown. One of the most straightforward possibilities is that they facilitate the otherwise small effects of very distal synapses (e.g., Spencer and Kandel, 1961; Deschênes, 1981; Amitai et al., 1993). In this scenario the depolarizations produced by EPSPs would, by activating voltage-dependent inward currents, generate much larger potentials over a longer distance than is possible in passive dendrites. It is very likely that active currents do amplify EPSPs in the apical dendrites of neocortical layer V cells. Purely passive cable models of these cells invariably predict that excitatory synapses in layer I, even if they are very strong, could generate only very small, slow EPSPs within the soma (Stratford et al., 1989; Cauller and Connors, 1992). However, cxpcrimental recordings show that layer I synapses can be very powerful at the level of the layer V soma (Cauller and Connors, 1992, in press).

Additional, more exotic, functions for active dendrites have been proposed. Excitability in dendritic membrane greatly alters the rules by which sets of synapses on a single neuron interact. Several modeling studies have noted that excitable dendrites could have a tendency to generate multiplicative computations (e.g., Shepherd and Brayton, 1987; Segev and Rall, 1988; Koch and Poggio, 1992). Under certain conditions, active dendritic branches could act as coincidence detectors (Jaslove, 1992). With strong, voltage-dependent inward currents, dendrites might also favor the coactivation of clustered synapses over more spatially distributed synapses and improve the capacity for information processing (Mel, 1992). It may be that active dendritic
A

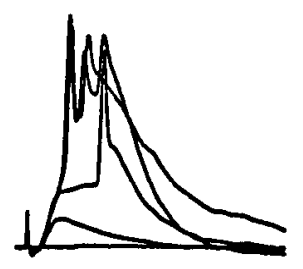

$10 \mathrm{mV}$

20 msec

$\mathrm{C}$

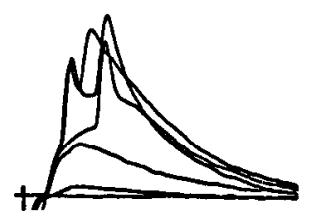

B

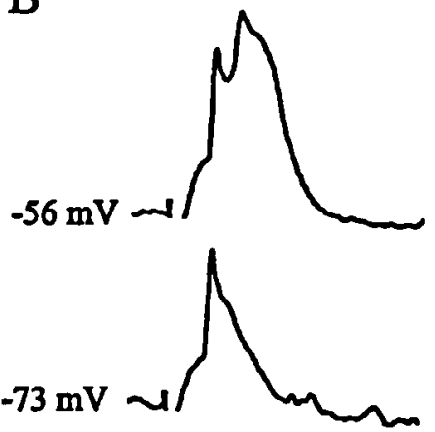

$\mathrm{D}$

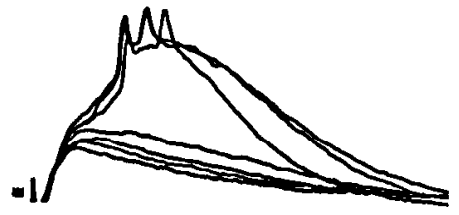

Figure 13. Fast and slow dendritic spikes evoked by layer I synaptic potentials. $A$, EPSPs generated by increasing stimulus levels of stimulus intensity while recording from a group II dendrite. As the stimulus intensity increased, multiple all-or-none events with different amplitudes and durations were generated. Resting potential was $-63 \mathrm{mV} . B$, A different group II dendrite produced two all-or-none events with different amplitude and duration when activated from layer I at a resting potential of $-56 \mathrm{mV}$. Hyperpolarizing the cell $(-73 \mathrm{mV})$ blocked the slow spike component but not the fast spike. This dendrite's response to injected currents is shown in Figure $7 A$. $C$ and $D$ ) illustrate two different group I dendritic recordings while activating layer I synapses at increasing intensities. Each generated all-or-none fast- and slow-spike events at relatively low thresholds.

currents are necessary both for efficient communication of distal synaptic inputs, and to allow richer computational capabilities.

The efficacy of distal synapses will be strongly influenced by any change in dendritic membrane properties, including the selective modulation of dendritic ion channels. For example, synaptic inhibition reduces the effect of layer I EPSPs on the somata of layer $V$ neurons (Cauller and Connors, in press), presumably by shunting synaptic and active currents of the apical dendrite. Since most (or all) membrane ion channels are modifiable by a variety of second messenger-mediated processes (McCormick, 1991), it is possible that neurotransmitter-mediated alterations in $\mathrm{Na}^{+}, \mathrm{Ca}^{2+}$, or $\mathrm{K}^{+}$currents could change the effective gain of distal inputs.

\section{References}

Agmon A, Connors BW (1991) Thalamocortical responses of mouse somatosensory (barrel) cortex in vitro. Neuroscience 41:365-380.

Agmon A, Connors BW (1992) Correlation between intrinsic firing patterns and thalamocortical responses of mouse barrel cortex neurons. J Neurosci 12:319-330.

Amitai Y, Friedman A, Connors BW, Gutnick MJ (1993) Regenerative activity in apical dendrites of pyramidal cells in neocortex. Cereb Cortex 3:26-38.

Arikuni T, Ochs S (1973) Slow depolarizing potentials and spike generation in pyramidal tract cells. J Neurophysiol 36:1-12.

Benardo L, Masukawa L, Prince DA (1982) Electrophysiology of isolated hippocampal pyramidal dendrites. J Neurosci 2:1614-1622.

Blanton MG, LoTurco JJ, Kriegstein AR (1989) Whole cell recording 
from neurons in slices of reptilian and mammalian cerebral cortex. J Neurosci Methods 30:203-210.

Brown AM, Schwindt PC, Crill WE (1992) Kinetics and voltage dependence of the high threshold calcium current in rat neocortical neurons. Soc Neurosci Abstr 18:430.

Carbone E, Swandulla D (1989) Neuronal calcium channels: kinetics, blockade and modulation. Prog Biophys Mol Biol 54:31-58.

Carbone E, Sher E, Clementi F (1990) Ca currents in human neuroblastoma IMR32 cells: kinetics, permeability and pharmacology. Pfluegers Arch 416:170-179.

Cauller LJ, Connors BW (1992) Functions of very distal dendrites: experimental and computational studies of layer I synapses on neocortical pyramidal cells. In: Single neuron computation (McKenna T, Davis J, Zornetzer SF, eds), pp 199-229. Boston: Academic.

Cauller LJ, Connors BW (in press) Synaptic physiology of long horizontal afferents to layer I of primary somatosensory cortex in rats. J Ncurosci, in press.

Chagnac-Amitai Y, Luhmann HJ, Prince DA (1990) Burst generating and regular spiking layer 5 pyramidal neurons of rat neocortex have different morphological features. J Comp Neurol 296:598-613.

Connors BW, Gutnick MJ (1990) Intrinsic firing patterns of diverse neocortical neurons. Trends Neurosci 13:99-104.

Connors BW, Gutnick MJ, Prince DA (1982) Electrophysiological properties of neocortical neurons in vitro. J Neurophysiol 48:13021320.

Deschênes M (1981) Dendritic spikes induced in fast pyramidal tract neurons by thalamic stimulation. Exp Brain Res 43:304-308.

Edwards FA, Konnerth A, Sakmann B, Takahashi T (1989) A thin slice preparation for patch clamp recordings from neurones of the mammalian central nervous system. Pfluegers Arch 414:600-612.

Fcldman ML (1984) Morphology of the neocortical pyramidal neuron. In: Cerebral cortex, Vol 1, Cellular components of the cerebral cortex (Peters A, Jones EG, eds), pp 123-200. New York: Plenum.

Fox AP, Nowycky MC, Tsien RW (1987) Kinetic and pharmacological properties distinguishing three types of calcium currents in chick sensory neurones. J Physiol (Lond) 394:149-172.

Franz P, Galvan M, Constanti A (1986) Calcium-dependent action potentials and associated inward currents in guinea-pig neocortical neurons in vitro. Brain Res 366:262-271.

Friedman A, Gutnick MJ (1987) Low-threshold calcium electrogenesis in neocortical neurons. Neurosci Lett 81:117-122.

Giffin K, Solomon JS, Burkhalter A, Nerbonne JM (1991) Differential expression of voltage-gated calcium currents in identified visual cortical neurons. Neuron 6:321-332.

Hamill OP, Marty A, Ncher E, Sakmann B, Sigworth FJ (1981) Improved patch-clamp techniques for high-resolution current recording from cells and cell-free membrane patches. Pfuegers Arch 391:85100.

Hamill OP, Huguenard JR, Prince DA (1991) Patch-clamp studies of voltage-gated currents in identified neurons of the rat cerebral cortex. Cereb Cortex 1:48-61.

Hillman DE (1979) Neuronal shape parameters and substructures as a basis of neuronal form. In: The neurosciences. Fourth study section (Schmitt FO, Worden FG, eds), pp 477-498. Cambridge, MA: MIT Press.

Hines M (1989) A program for simulation of nerve equations with branching geometries. Int J Biomed Comput 24:55-68.

Horikawa K, Armstrong WE (1988) A versatile means of intracellular labclling: injection of biocytin and its detection with avidin conjugates. J Neurosci Methods 25:1-11.

Huguenard JR, Hamill O, Prince DA (1989) Sodium channels in dendrites of rat cortical pyramidal cells. Proc Natl Acad Sci USA 86: 2473-2477.

Jaffe DB, Johnston D, Lasser-Ross N, Lisman JE, Miyakawa H, Ross WN (1992) The spread of $\mathrm{Na}^{+}$spikes determines the pattern of dendritic $\mathrm{Ca}^{2+}$ entry into hippocampal neurons. Nature 357:244-246.

Jaslove SW (1992) The integrative properties of spiny distal dendrites. Neuroscience 47:495-519.

Kim HG, Connors BW (1992) Calcium currents in the apical dendrites of neocortical pyramidal neurons. Soc Neurosci Abstr 18:217.

Koch C, Poggio T (1992) Multiplying with synapses and neurons. In: Single neuron computation (McKenna T, Davis J, Zornetzer SF, eds), pp 315-345. Boston: Academic.

Larkman AU (1991a) Dendritic morphology of pyramidal neurons in the visual cortex of the rat: I. Branching patterns. J Comp Neurol 306:306-319.
Larkman AU (1991b) Dendritic morphology of pyramidal neurons in the visual cortex of the rat: II. Parameter correlations. J Comp Neurol 306:320-331.

Larkman AU, Mason A (1990) Correlations between morphology and electrophysiology of pyramidal neurons in slices of rat visual cortex. I. Establishment of cell classes. J Neurosci 10:1407-1414.

Llinás R, Nicholson C (1971) Electrophysiological properties of dendrites and somata in alligator Purkinje cells. J Neurophysiol 34:534 551.

Llinás R, Sugimori M (1981) Electrophysiological properties of in vitro Purkinje cell dendrites in mammalian cerebellar slices. J Physiol (Lond) 305:197-213.

Llinás R, Sugimori M, Lin J-W, Cherksey B (1989) Blocking and isolation of a calcium channel from neurons in mammals and cephalopods utilizing a toxin fraction (FTX) from funnel-web spider poison. Proc Natl Acad Sci USA 86:1689-1693.

Mason A, Larkman A (1990) Correlations between morphology and electrophysiology of pyramidal neurons in slices of rat visual cortex. II. Electrophysiology. J Neurosci 10:1415-1428.

McCormick DA (1991) Neurotransmitter actions in the thalamus and cerebral cortex and their role in neuromodulation of thalamocortical activity. Prog Brain Res 39:337-388.

McCormick DA, Connors BW, Lighthall JW, Prince DA (1985) Comparative electrophysiology of pyramidal and sparsely spiny neurons of the neocortex. J Neurophysiol 54:782-806.

Mel BW (1992) NMDA-based pattern discrimination in a modeled cortical neuron. Neural Comp 4:502-516.

Mel BW (in press) Synaptic integration in an excitable dendritic tree. $\mathrm{J}$ Neurophysiol, in press.

Pockberger H (1991) Electrophysiological and morphological properties of rat motor cortex neurons in vivo. Brain Res 539:181-190.

Purpura DP (1967) Comparative physiology of dendrites. In: The neurosciences (Quarton C, Melnechuck T, Schmitt FO, eds), pp 372393. New York: Rockefeller UP.

Purpura DP, Shofer RJ (1964) Cortical intracellular potentials during augmenting and recruiting responses. I. Effects of injected hyperpolarizing currents on evoked membrane potential changes. J Neurophysiol 27:117-132.

Purpura DP, Shofer RJ, Scarff T (1965) Properties of synaptic activities and spike potentials of neurons in immature neocortex. J Neurophysiol 28:925-942.

Rall W (1977) Core conductor theory and cable properties of neurons. In: Handbook of physiology, Sec 1, The nervous system, Vol 1 (Kandel ER, ed), pp 39-98. Bethesda: American Physiological Society.

Regehr WG, Konnerth A, Armstrong CM (1992) Sodium action potentials in the dendrites of cerebellar Purkinje cells. Proc Natl Acad Sci USA 89:5492-5496.

Reuveni I, Friedman A, Amitai Y, Gutnick MJ (1993) Stepwise repolarization from $\mathrm{Ca}^{2+}$ plateaus in neocortical pyramidal cells: evidence for nonhomogeneous distribution of $\mathrm{HVA} \mathrm{Ca}^{2+}$ channels in dendrites. J Neurosci 13:4609-4621

Ross WN, Lasser-Ross N, Werman R (1990) Spatial and temporal analysis of calcium-dependent electrical activity in guinea pig Purkinje cell dendrites. Proc R Soc Lond [Biol] 240:173-185.

Sakmann B, Neher E (1983) Single channel recording. New York: Plenum.

Sayer RJ, Schwindt PC, Crill WE (1990) High-threshold and lowthreshold calcium currents in neurons acutely isolated from rat sensorimotor cortex. Neurosci Lett 120:175-178.

Segev I, Rall W (1988) Computational study of an excitable dendritic spine. J Neurophysiol 60:499-523.

Shepherd GM, Brayton RK (1987) Logic operations are properties of computer-simulated interactions between excitable dendritic spines. Neuroscience 21:151-166.

Silva LR, Amitai A, Connors BW (1991) Intrinsic oscillations of neocortex generated by layer 5 pyramidal neurons. Science 251:432-435.

Spencer WA, Kandel ER (1961) Electrophysiology of hippocampal neurons. IV. Fast prepotentials. J Neurophysiol 24:272-285.

Stafstrom CE, Schwindt PC, Crill WE (1984) Repetitive firing in layer $\mathrm{V}$ neurons from cat neocortex in vitro. J Neurophysiol 52:264-277.

Stafstrom CE, Schwindt PC, Chubb MC, Crill WE (1985) Properties of persistent sodium conductance and calcium conductance of layer $\mathrm{V}$ neurons from cat sensorimotor cortex in vitro. J Neurophysiol 53: 153-170.

Stratford K, Mason A, Larkman A, Major G, Jack J (1989) The modeling of pyramidal neurones in the visual cortex. In: The computing 
neuron (Durbin R, Mial C, Mitchison G, eds), pp 296-321. Menlo Park, CA: Addison-Wesley.

Sutor B, Zieglgänsberger W (1987) A low-voltage activated, fully inactivated, transient calcium current is responsible for the time-dependent depolarizing inward rectification or rat neocortical neurons in vitro. Pfluegers Arch 410:102-111.

Telfeian AE, Cauller LJ, Connors BW (1991) Contribution of apical dendrites to somatic membrane properties of layer $\mathrm{V}$ pyramidal cells in neocortex. Soc Neurosci Abstr 17:311.

Tsien RW, Lipscombe D, Madison DV, Bley KR, Fox AP (1988) Multiple types of neuronal calcium channels and their selective modulation. Trends Neurosci 11:431-438.
Turner RW, Meyers DE, Richardson TL, Barker JL (1991) The site for initiation of action potential discharge over the somatodendritic axis of rat hippocampal CA1 pyramidal neurons. J Neurosci 11:2270 2280.

Westenbroek RE, Hell JW, Warner C, Dubel SJ, Snutch TP, Catterall WA (1992) Biochemical properties and subcellular distribution of an N-type calcium channel $\alpha 1$ subunit. Neuron 9:1099-1115.

Wong RKS, Prince DA, Basbaum AI (1979) Intradendritic recordings from hippocampal neurons. Proc Natl Acad Sci USA 76:986-990.

Woody CD, Gruen E, McCarley K (1984) Intradendritic recordings from neurons of motor cortex of cats. J Neurophysiol 51:925-938. 